Reframing Biblical Studies 
This page intentionally left blank. 


\section{Reframing Biblical Studies}

When Language and Text Meet Culture, Cognition, and Context

\section{ELLEN VAN WOLDE}

Winona Lake, Indiana

EISENBRAUNS

2009 
(C) Copyright 2009 by Ellen van Wolde.

All rights reserved.

Printed in the United States of America.

www.eisenbrauns.com

\section{Library of Congress Cataloging-in-Publication Data}

Wolde, E. J. van.

Reframing biblical studies : when language and text meet culture, cognition, and context / Ellen van Wolde.

p. $\mathrm{cm}$.

Includes bibliographical references and index.

ISBN 978-1-57506-182-5 (hardback : alk. paper)

1. Bible. O.T.-Criticism, interpretation, etc. 2. Bible. O.T.-

Language, style. 3. Hebrew Language-Semantics, Historical.

4. Cognitive grammar. I. Title.

BS511.3.W663 2009

$221.6^{\prime} 6-\mathrm{dc} 22$

The paper used in this publication meets the minimum requirements of the American National Standard for Information Sciences-Permanence of Paper for Printed Library Materials, ANSI Z39.48-1984. @ ${ }^{\mathrm{TM}}$ 